\title{
COMPARATIVE STUDY BETWEEN EXPERIMENTAL RESULTS AND THE NUMERICAL ONE OF THE LATERAL BUCKLING RESISTENCE FOR THE TWO CURVED I GIRDERS OF A CURVED BRIDGE MODEL
}

Marian Daraban, Asist. dr. ing., Technical University of Civil Engineering Bucharest, email: marian_daraban@cfdp.utcb.ro

\section{Rezumat}

Articolul prezintă un studiul al rezistenţei la flambaj lateral pentru grinzile curbe utilizate la poduri.

Rezistenţa la flambaj lateral va fi evaluată printr-o analiză geometric şi fizic neliniară utilizând programul de calcul Lusas ${ }^{\circledR}$, fară a considera imperfecţiunile de execuţie. Pentru a da veridicitate rezultatelor analitice, studiul numeric se va realiza pe unul din modelele fizice prezentate în lucrarea [1] care pune la dispoziţie valori ale încercărilor experimentale.

Geometria modelului fizic din lucrarea [1] se bazează pe o analiză dimensională a grinzilor curbe „I” utilizate în mod frecvent la poduri. Modelul fizic este alcătuit din două grinzi I curbe, dublu simetrice, prevăzute cu antretoaze şi contravântuiri la nivelul tălpilor. De antretoazele de capăt sunt sudate pe direcţia axei curbe două console scurte de lungime $e$.

Schema statică a structurii este grinda simplu rezemată cu console, ale cărei aparate de reazem sunt dispuse pe direcţia coardei. Consolele scurte vor fi încărcate cu prese hidraulice la o forţă $\mathrm{P}$ care are ca efect în grinda principală un moment încovoietor uniform având valoarea $P^{*} e$ şi forţă tăietoare zero.

Pentru analiza neliniară s-a folosit formularea Total Lagrange, împreună cu utilizarea metodei lungimii arcului modificat formulată de Crisfield. De asemenea s-a considerat comportarea neliniară a materialului.

Evaluarea rezistenţei la flambaj lateral constă în determinarea momentului încovoietor critic pentru care grinda îşi pierde stabilitatea. Comparaţia rezultatelor numerice cu cele experimentale preluate, confirmă posibilitatea evaluării numerice a rezistenţei la flambaj lateral pentru grinzile curbe.

Cuvinte cheie: Flambaj lateral, poduri curbe, analiză neliniară)

\section{Abstract}

This article deals with the problem of lateral buckling of curved I girders used in bridge structures. 
ROMANIAN JOURNAL

OF TRANSPORT INFRASTRUCTURE

Marian Daraban,

Comparative study between experimental results and the numerical one of the lateral buckling resistance for the two curved I girders of a curved bridge model

Lateral buckling resistance will be evaluated, by a geometrically and physically nonlinear analysis, using the computer program Lusas ${ }^{\circledR}$, without considering imperfections of execution.

In order to validate the analytical results, numerical study will be performed on a physical model presented in paper [1] which provides values of experimental tests.

The geometry of the physical model presented in paper [1] is based on a dimensional analysis of a curved girder used frequently for bridges construction. The physical model consists of two curved I girders, double symmetrical, provided with cross beams and upper and lower bracings. Each end cross beam has welded in girder axis direction a short cantilever beam with length value e.

The model girder is supported on a roller at one end and a pin at the other, which are disposed on chord direction. The short cantilever beams are loaded by hydraulic presses with a force $\mathrm{P}$, which causes constant bending moment with value $P^{*} e$ and shear zero.

The nonlinear analysis uses the Total Lagrangian formulation and the Crisfield modified arc length method. The numerical model also considers nonlinear behavior of the material.

Resistance to lateral buckling assessment consists in determining the critical bending moment for which the beam is losing stability. The comparison of numerical with the experimental results, confirms the possibility of using the numerical evaluation for estimating the lateral buckling resistance for curved bridge girders.

\section{Keywords: Lateral buckling, curved bridges, nonlinear analysis}

\section{LATERAL BUCKLING REZISTANCE FOR CURVED I GIRDERS. ANALYTICAL STUDY [1]}

Lateral Buckling of multiple curved I girders can be classified into two categories:

- Overall buckling (inflection point on the bearing);

- Local buckling between the supports point such as floor beams or sway and lateral bracings;

Horizontal displacement, the vertical one, and also the rotation angle of the girder will always occur even though the applied bending moment is relatively small. For a given value of bending moment, called critical moment, the curved girder bows out sideways, losing its stability.

Using a theory based on a second-order analysis, the phenomenon of lateral buckling can be studied. The following relationship between displacements and stress resultants can be obtained by referring to Fig. 2: 


$$
\begin{aligned}
& E \cdot I_{X}\left(\frac{d^{2} w}{d s^{2}}-\frac{\beta}{R_{s}}\right)+E \cdot I_{X Y}\left(\frac{d^{2} y}{d s^{2}}+\frac{1}{R_{S}} \frac{d u}{d s}\right)=-\frac{R_{0}}{R_{S}} M_{\bar{\eta}} \\
& E \cdot I_{Y}\left(\frac{d^{2} v}{d s^{2}}+\frac{1}{R_{s}} \cdot \frac{d u}{d s}\right)+E \cdot I_{X Y}\left(\frac{d^{2} w}{d s^{2}}-\frac{\beta}{R_{S}}\right)=\frac{R_{0}}{R_{S}} M_{\bar{\zeta}} \\
& E \cdot A_{Z} \cdot\left(\frac{d u}{d s}-\frac{v}{R_{s}}-\left(\frac{d^{2} w}{d s^{2}}-\frac{\beta}{R_{s}}\right) \cdot y_{s}-\left(\frac{d^{2} v}{d s^{2}}+\frac{1}{R_{s}} \frac{d u}{d s}\right) \cdot x_{s}\right)=\frac{R_{0}}{R_{S}} \cdot N_{\bar{\xi}} \\
& E \cdot I_{w} \cdot \frac{d^{2} \theta}{d s^{2}}-\overline{G \cdot K} \frac{d \theta}{d s}=-T_{\bar{\xi}}
\end{aligned}
$$

where:

$s=$ curvilinear coordinate at shear center;

$x, y, z=$ horizontal, vertical and axial coordinate axes, respectively, at shear center;

$u, v, w=$ displacement in the direction of $\mathrm{z}, \mathrm{x}$ and $\mathrm{y}$ coordinate axes, respectively;

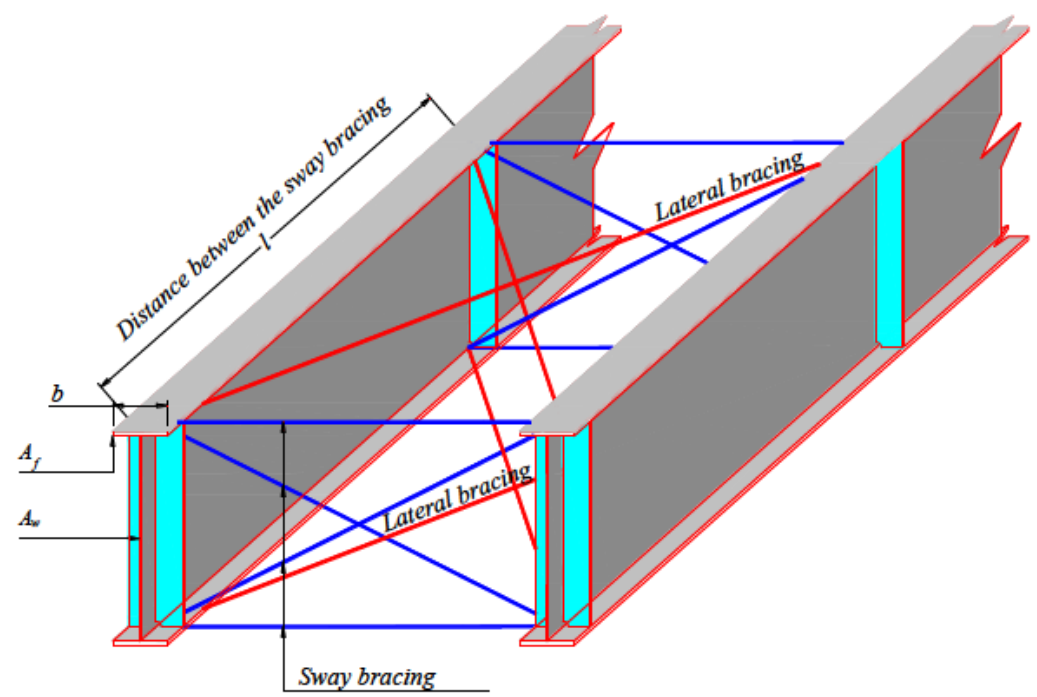

Figure 1. Distance between the sway bracing which are point of support for compressed flange

$\theta=\beta+\frac{w}{R_{s}}$

$\beta$

$E I_{X}, E I_{Y}, E I_{X Y}$

$E A_{2}$

$E I_{w}$ torsional angle;

rotational angle

flexural rigidity with respect to centroidal $\mathrm{X}, \mathrm{Y}, \mathrm{XY}$;

elongation rigidity;

warping rigidity; 
$\mathrm{G} \cdot \mathrm{K} \quad$ torsional rigidity;

$\overline{G K}=G K+\int_{A}\left(x^{2}+y^{2}\right) \sigma d A$

$\int_{A}\left(x^{2}+y^{2}\right) \sigma d A \quad$ additional torsional rigidity due to normal stress;

$R_{0}, R_{S}$

radius of curvature at centroid $C^{\prime}$ and shear center $S^{\prime}$;

$x_{S}, y_{S}$ eccentricity between $\mathrm{C}^{\prime}$ and $\mathrm{S}^{\prime}$ in the direction of $\mathrm{x}$ and $\mathrm{y}$ coordinate axes, respectively;

The additional stress resultants in the right-hand side at state 2 through state 1 can be written as::

$N_{\bar{\xi}}=0$

$M_{\eta}=-T_{z}^{0} \cdot \varphi_{y}$

$M_{\bar{\xi}}=-M_{X}^{0} \cdot \beta+T_{z}^{0} \cdot \varphi_{x}$

$T_{\xi}=M_{X}^{0} \cdot \varphi_{y}$

When a girder is subjected to only a bending moment about the strong axes at the ends of the girder $\phi=0$ and $\phi=\Phi$, the bending moment $M_{Y}^{0}$ and torsional moment $T_{z}^{0}$ at an arbitrary section $\phi$ will be reduced to:

$M_{X}^{0}=\frac{M_{0} \cdot \cos (\phi-\Phi / 2)}{\cos (\Phi / 2)}$

$T_{z}^{0}=\frac{M_{0} \cdot \sin (\phi-\Phi / 2)}{\cos (\Phi / 2)}$

Moreover, the warping moment $M_{w}^{0}$ can be determined by solving the following equation:

$\frac{d^{2} M_{w}^{0}}{d s^{2}}-\frac{G K}{E I_{w}} \cdot M_{w}^{0}=-\frac{M_{0}}{R_{0}}$

The deflection angles $\varphi_{x}$ and $\varphi_{y}$ due to bending can also be found from:

$\varphi_{x}=-\frac{d w}{d s}$

$\varphi_{y}=\frac{d v}{d s}+\frac{u}{R_{s}}$ 
ROMANIAN JOURNAL

OF TRANSPORT INFRASTRUCTURE

Marian Daraban,

Comparative study between experimental results and the numerical one of the lateral buckling resistance for the two curved I girders of a curved bridge model

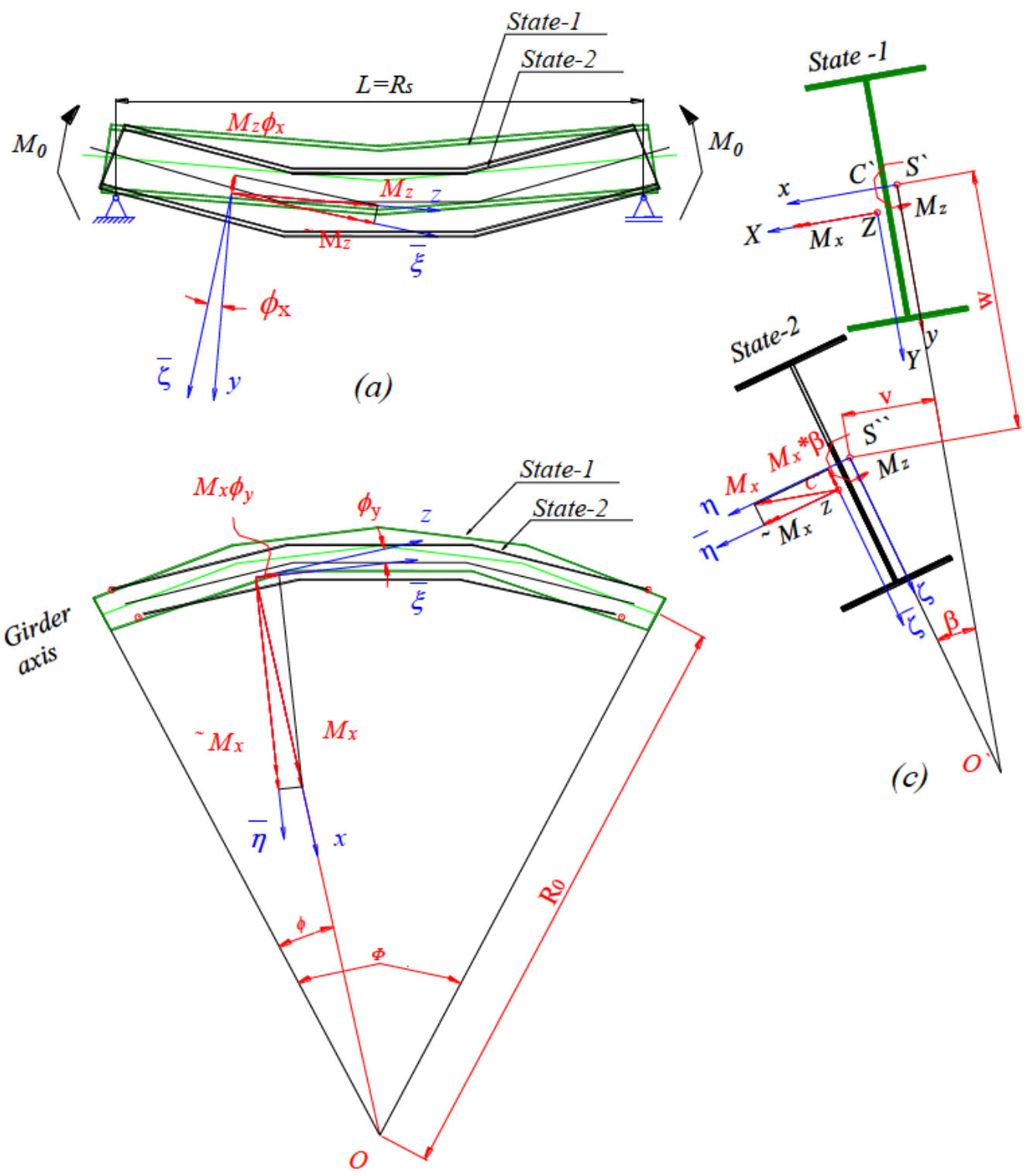

(b)

a) side elevation b) plan c) cross section

Figure 2. Buckling displacement and additional stress resultants

Accordingly, the substitution of Eqs. (2)... (7) into Eq. (4) gives a set of simultaneous differential equations for the lateral buckling displacements $u, v, w, \beta, \theta$ as follows: 
$E I_{X}\left(\frac{d^{4} w}{d s^{4}}-\frac{1}{R_{s}} \frac{d^{2} \beta}{d s^{2}}\right)-\frac{d^{2}}{d s^{2}}\left[T_{z}^{0}\left(\frac{d v}{d s}+\frac{u}{R s}\right)\right]-\frac{d^{2}}{d s^{2}}\left(M_{X}^{0} \beta+T_{z}^{0} \frac{d w}{d s}\right) \frac{I_{X Y}}{I_{Y}}=0$

$E I_{Y}\left[\frac{R_{S}}{R_{0}}\left(\frac{d^{4} v}{d s^{4}}+\frac{1}{R_{S}^{2}} \frac{d^{2} v}{d s^{2}}\right)+\frac{y_{s}}{R_{0}}\left(\frac{d^{4} w}{d s^{4}}-\frac{1}{R_{s}} \cdot \frac{d^{2} \beta}{d s^{2}}\right)\right]+$

$+\frac{d^{2}}{d s^{2}}\left(M_{X}^{0} \beta+T_{y}^{0} \cdot \frac{d w}{d s}\right)+\frac{d^{2}}{d s^{2}}\left(T_{y}^{0} \cdot \varphi_{y}\right) \frac{I_{X Y}}{I_{X}}=0$

$E I_{w} \frac{d^{4} \theta}{d s^{4}}-\overline{G K} \frac{d^{2} \theta}{d s^{2}}+\frac{d}{d s}\left[M_{X}^{0}\left(\frac{d v}{d s}+\frac{u}{R_{x}}\right)\right]=0 \quad$ where:

$u=\int_{0}^{s} \frac{v}{R_{s}} d s+u_{0} \quad u_{0}=$ axial displacement at the origin $\mathrm{s}=0$

and $I_{x}$ and $I_{y}$ are defined as:

$$
\begin{aligned}
& I_{x}=\frac{R_{s}}{R_{0}} \cdot\left(I_{X}-\frac{I_{X Y}^{2}}{I_{X}}\right) \\
& I_{y}=\frac{R_{s}}{R_{0}} \cdot\left(I_{Y}-\frac{I_{X Y}^{2}}{I_{X}}\right)
\end{aligned}
$$

The boundary conditions for displacements and stress resultants for a simply supported curved I girder can be set as:

$$
\begin{aligned}
& v=w=\beta=\varphi_{z}=T_{s}=0 \\
& M_{X}=M_{0}
\end{aligned}
$$

At both ends $\phi=0$ and $\phi=\Phi$ and $u=0$ and $N_{Y}=0$

For the analyses of the material nonlinearity, a cross section of the girder is divided into small elements, as shown, and the following assumption are made to estimate the elasto-plastic behavior for each element:

- The material behaves as an ideal elasto-plastic;

- The Bernoulli-Euler hypothesis can be applied to both the bending strain $\varepsilon_{b}\left[=M_{X}^{0} /\left(E I_{Y} Z\right)\right]$ and warping strain $\varepsilon_{b}\left[=M_{w}^{0} /\left(E I_{w} w\right)\right]$ as illustrated in Fig. 3.a and Fig.3b.

- The residual stress distributions are shown in Fig. 3.c., in which the residual strain is defined as $\varepsilon_{r}=\sigma_{r} / E$; 
ROMANIAN JOURNAL

OF TRANSPORT INFRASTRUCTURE

- The stiffness of the element vanishes when the sum of the strain exceeds the yield strain $\varepsilon_{y}=\sigma_{y} / E$ of the material;

Thus, Eq. (10) can be successively solved by determining the rigidities $E I_{X}, E I_{Y}, E I_{X Y}$ and $E I_{w}$ on the basis of the above assumptions by regarding this problem as an eigenvalue problem.

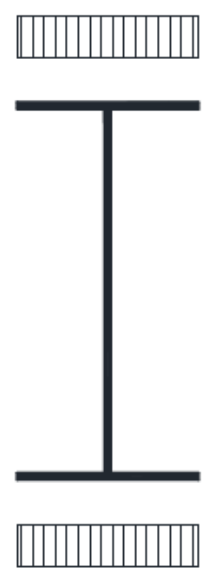

(a)
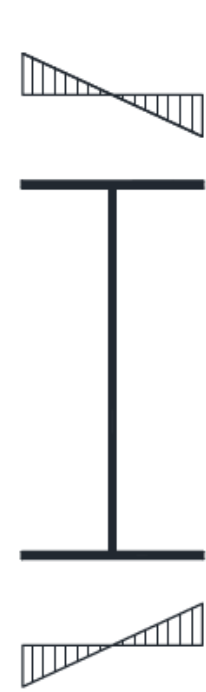

(b)

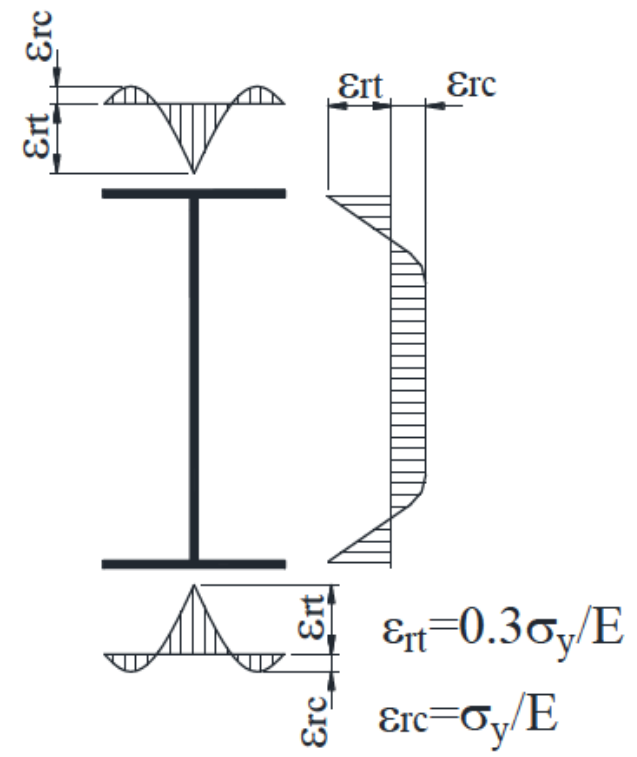

(c)

a) bending strain $\varepsilon b \quad$ b) warping strain $\mathrm{e}_{\mathrm{w}}$ Figure 3. Strain distribution in I girder

\section{NUMERICAL ANALISYS OF LATERAL BUCKLING FOR A CURVED I GIRDER BRIDGE MODEL.}

\subsection{Description of bridge model}

The study performed in paper [1] contains three model girder bridges MG-1, MG-2 and MG-3 with two main girder provided with lateral bracing and sway bracing built on scale 1:3,8 based on a dimensional analysis of actual multiple curved I-girder bridges. Fig.5 and Fig. 6. presents plan, respectively cross section of bridge model MG1. The ratio between the span length $\mathrm{L}$ and girder spacing $\mathrm{B}$ was $\mathrm{L} / \mathrm{B}=5.56 \mathrm{~m}$.

The cross sections of lateral bracing in model girders MG-1, MG-2, MG3 , were, respectively, chosen to have 2,1 , and o,5 times the cross-sectional area of lateral bracings based on a dimensional analysis of actual bridges, as shown in Fig. 7. 
ROMANIAN JOURNAL

OF TRANSPORT INFRASTRUCTURE

Marian Daraban,

Comparative study between experimental results and the numerical one of the lateral buckling resistance for the two curved I girders of a curved bridge model

The girders are simply supported, on a roller at one end and a pin at the other the bearings are positioned so as the translations of the girder in the chord direction to be free.

The lateral buckling test was performed under a condition where the shearing force will not appear as in the pure bending of a straight beam.
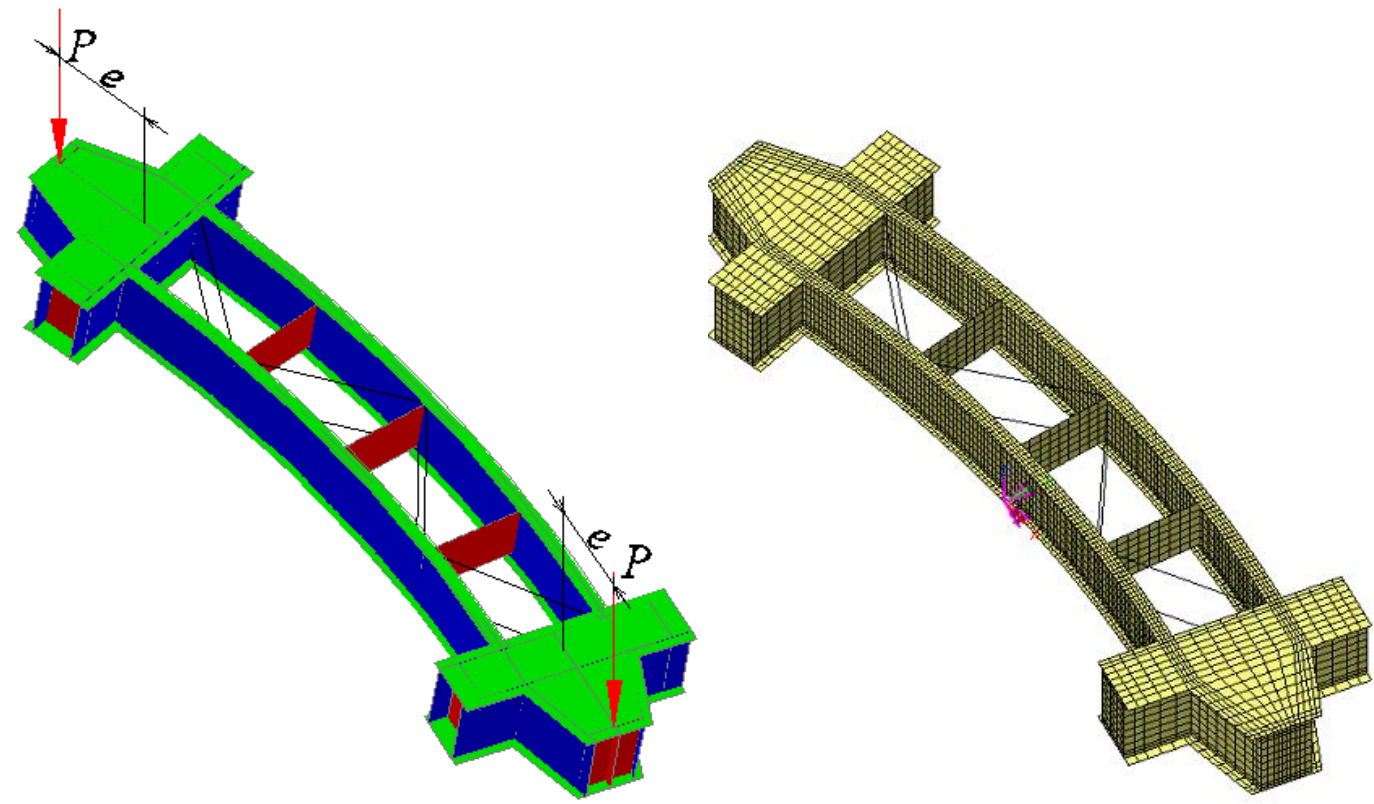

Figure 4. 3D view of bridge model with load conditions and 3D view of the numerical model

To satisfy this condition as exactly as possible, two loading beams with cantilever tongues were bolted to the model girders. The ends of cantilevers were loaded by hydraulic jacks. Thus, the model girder can be approximately subjected to the pure bending moment $M=P \cdot e$, where $e$ is the eccentricity of load $P$.

All members of the model bridge were made of structural steel SS-41 with Young`s modules $E=2.1 \times 10^{6} \mathrm{kgf} / \mathrm{cm}^{2}$, Poisson`s ratio $\mu=0.3$, and yield stress $\sigma_{y}=3100 \mathrm{kgf} / \mathrm{cm}^{3}$ and ultimate strength $\sigma_{u}=4200 \mathrm{kgf} / \mathrm{cm}^{3}$. 
ROMANIAN JOURNAL

OF TRANSPORT INFRASTRUCTURE

Marian Daraban,

Comparative study between experimental results and the numerical one of the lateral buckling resistance for the two curved I girders of a curved bridge model

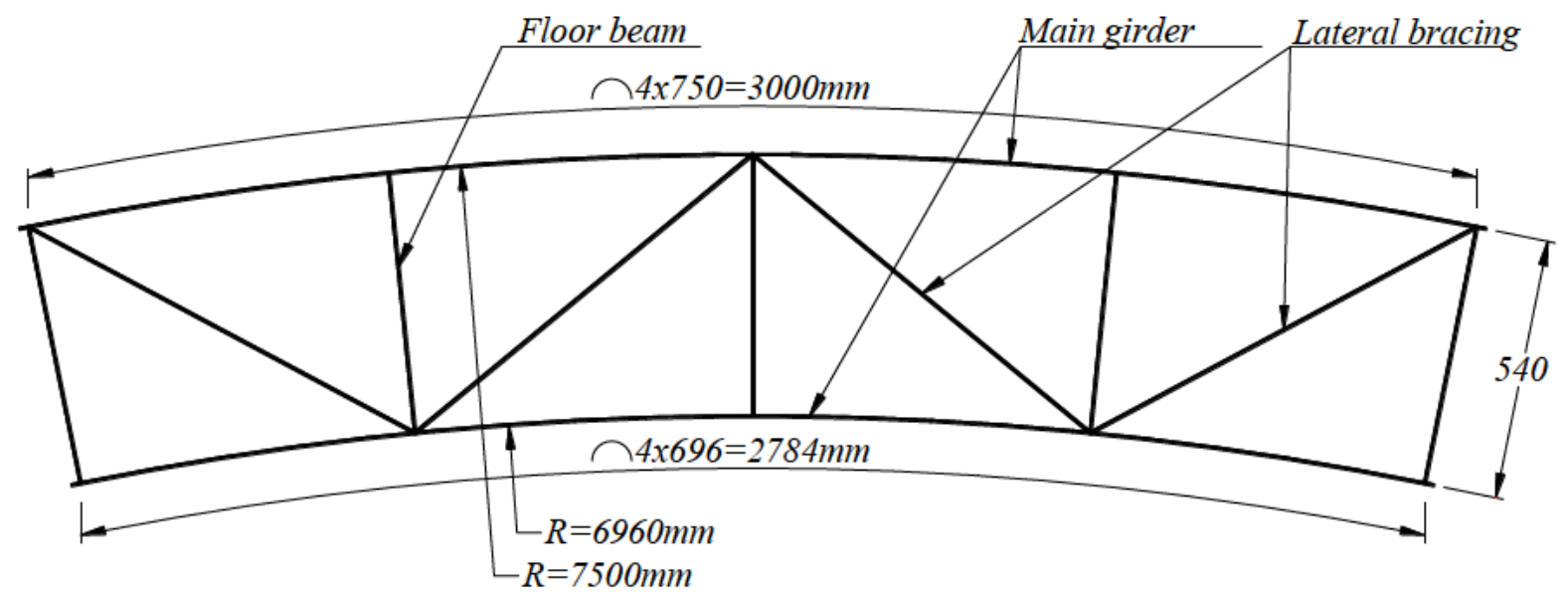

Figure 5. Plan of model girder (mm)

Top lateral bracing attached by gusset plate

Bottom lateral bracing

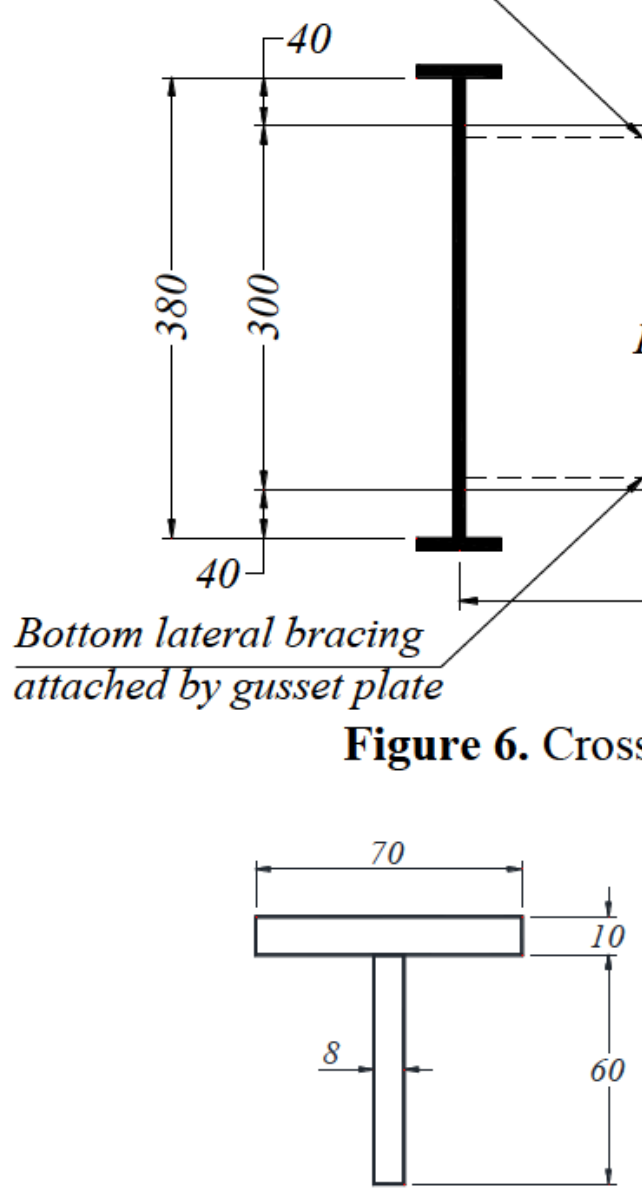
$\frac{\text { Top flange plate }}{70 \times 10}$

Floor beam

Plate $300 \times 530 \times 10$

$M G-1$

Figure 7. Cross section of lateral bracings (mm) 
ROMANIAN JOURNAL

OF TRANSPORT INFRASTRUCTURE

Marian Daraban,

Comparative study between experimental results and the numerical one of the lateral buckling resistance for the two curved I girders of a curved bridge model

\subsection{Description of numerical bridge model}

For the bridge model MG1 a numerical analysis was performed using a finite element program, Lusas ${ }^{\circledR}$. The bridge model and applied loads considered were idealized with the purpose to make a comparison between the experimental results and the analytical one. For the numerical model were used frame elements ( BXL4) for lateral bracing and thick shell elements ( QTS4 ) for curved girders webs an flanges.

QTS4

BXL4
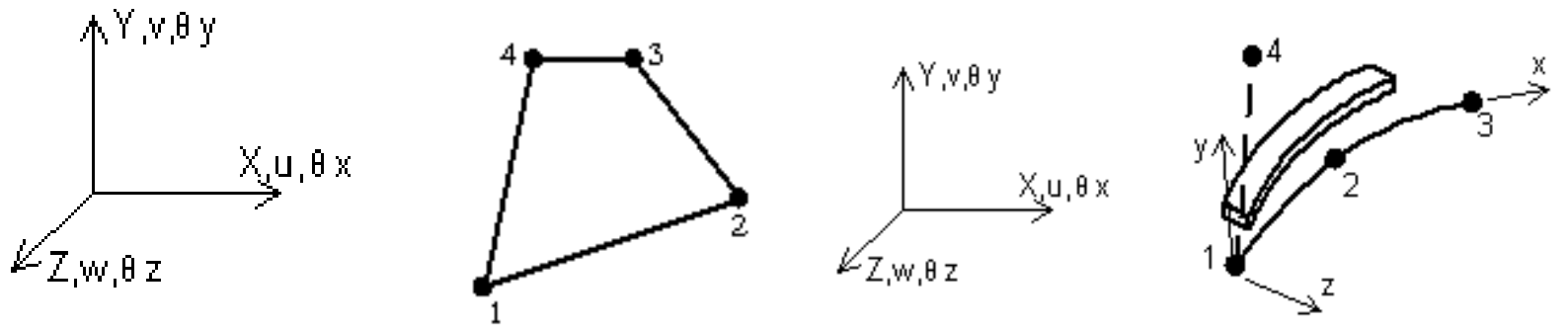

Figure 8. QTS4 thick Shell element, and BXL4 frame element [2]

The nonlinear analysis has used Total Lagrange formulation, with arc length method, made of Crisfield. Also nonlinear behavior of steel was considered because the critical buckling moment leads to normal stresses in flanges higher than the yield strength of steel, fy.

On each cantilever beam were applied two forces of 1 tf with an eccentricity of $0,5 \mathrm{~m}$ from the axis of the bearing beam. The incremental analysis starts from the loading applied to the first increment and it will be multiplied by the load factor which in this case will have a maximum value of 45 , corresponding to a total force of $90 t f$ and a bending moment on girder of $45 t f \cdot m$.

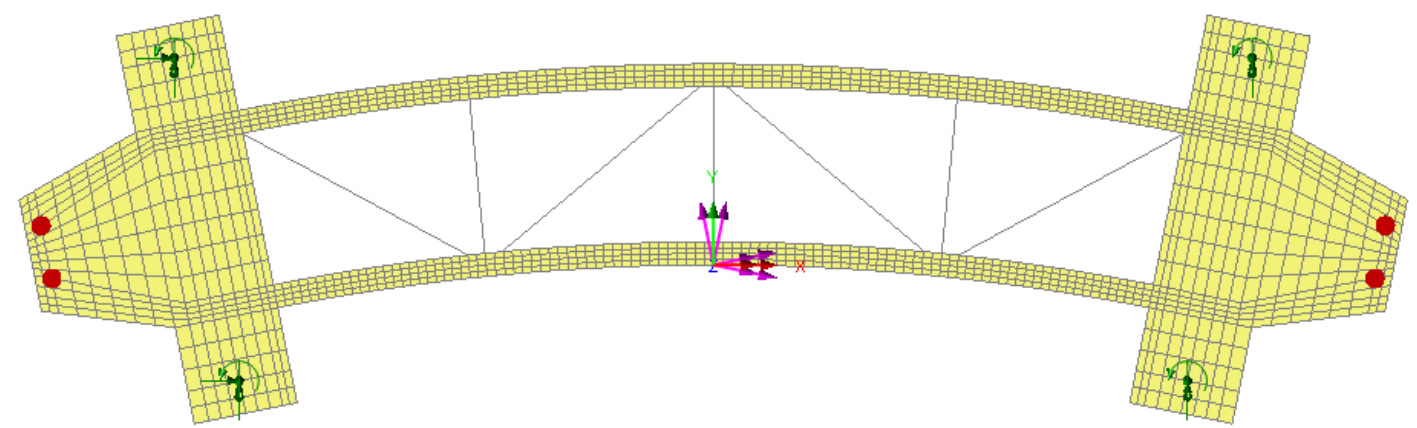

Figure 9. The degrees of freedom of bearings and the position of applied forces on the numerical model 
ROMANIAN JOURNAL

OF TRANSPORT INFRASTRUCTURE

Marian Daraban,

Comparative study between experimental results and the numerical one of the lateral buckling resistance for the two curved I girders of a curved bridge model

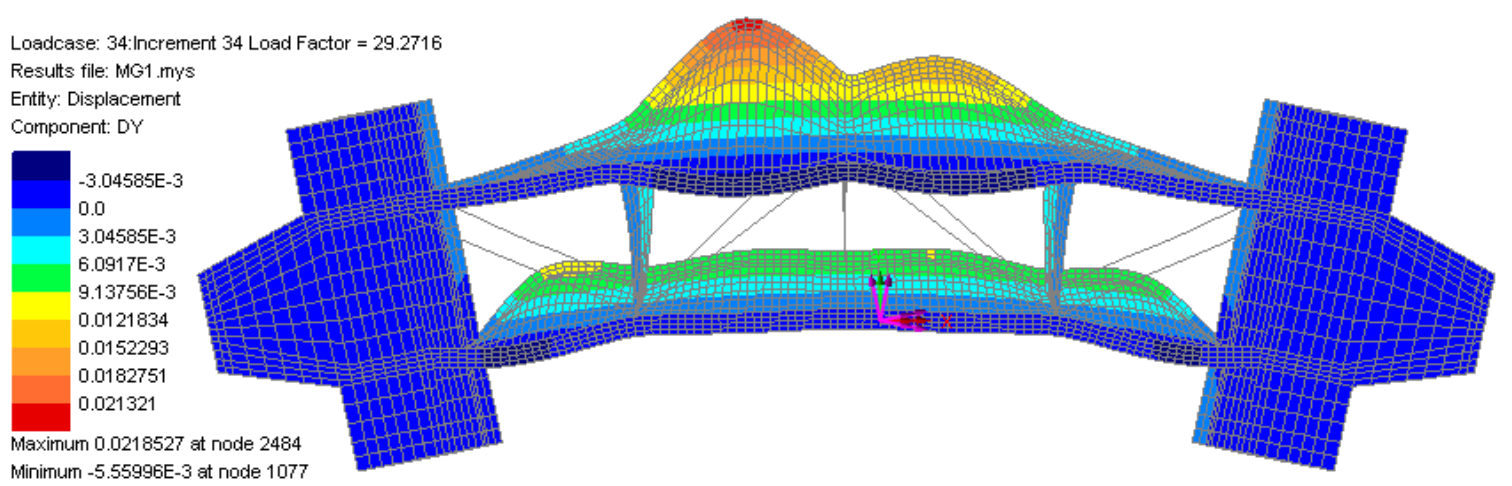

Figura 10. The deformed shape corresponding to load factor 29.27 (numerical values for $\Delta y$ )

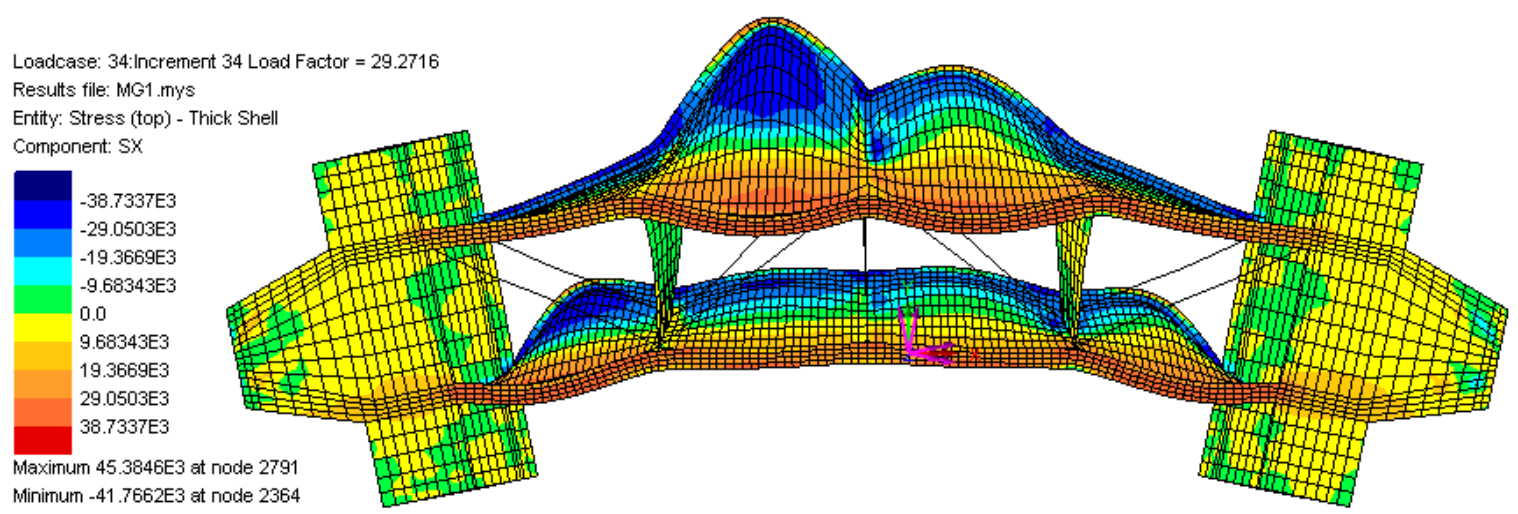

Figura 11. The deformed shape corresponding to load factor 29.27 (numerical values for $\sigma_{x}$ )

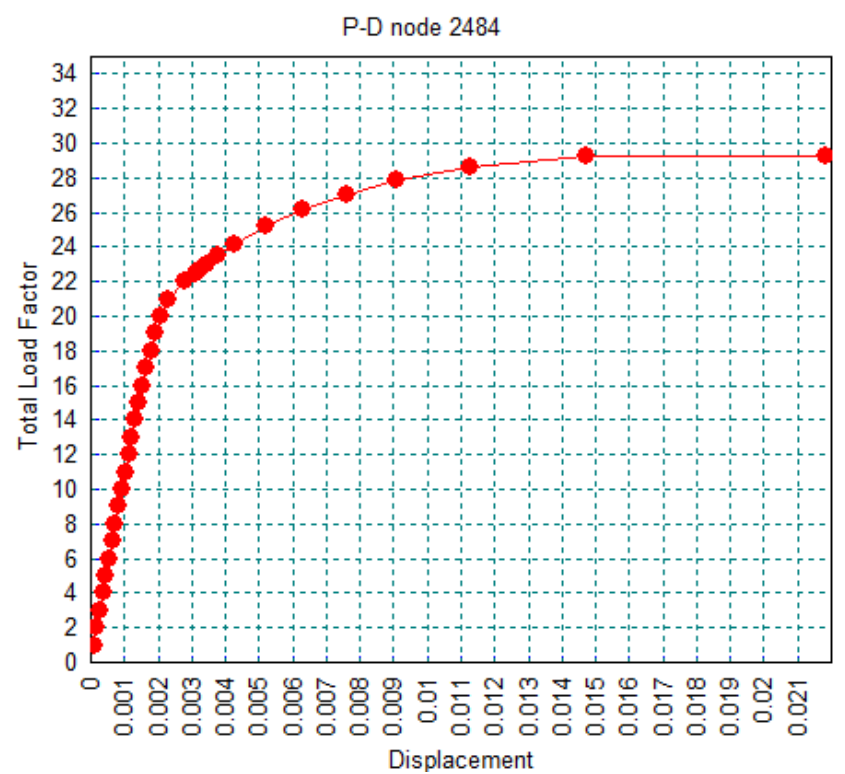

Figura 12. P- $\Delta$ coresponding for 2484 joint which has the maximum lateral displacement $(\Delta y=\max )$ 
ROMANIAN JOURNAL

OF TRANSPORT INFRASTRUCTURE

Marian Daraban,

Comparative study between experimental results and the numerical one of the lateral buckling resistance for the two curved I girders of a curved bridge model

\section{CONCLUSIONS}

The critical value obtained by numerical calculation is $29,27 \cdot 2 \cdot 1 t f=58.54 t f$, and critical value of bending moment: $58,54 \cdot 0,5 \mathrm{~m}$ $=29,27 \mathrm{tf} \cdot \mathrm{m}$. The experimental value of the critical momento is $30,38 \mathrm{t} f \cdot \mathrm{m}$, resulting a difference between the calculated and measured the critical moment of $3,8 \%$, which confirms the possibility of numerical assessment of resistance to lateral buckling of bridges curved I girder.

\section{REFERENCES}

[1]. Hiroshi Nakai, Chai Hog Yoo, "Analysis and Design of Curved Steel Bridges”, Ohio, U.S.A: McGraw-Hill, 1988;

[2]. Manual LUSAS Version 14.7 : Issue 1 LUSAS Forge House, 66 High Street, Kingston upon Thames, Surrey, KT1 1HN, United Kingdom, 2012;

[3]. M. Daraban, "Concepția şi calculul structurilor curbe de poduri din oţel”, Thesys, Technical University of Civil Engineering Bucharest, 2012. 